Georgetown University Law Center

Scholarship @ GEORGETOWN LAW

2003

\title{
Their Liberties, Our Security: Democracy and Double Standards
}

David Cole

Georgetown University Law Center, cole@law.georgetown.edu

This paper can be downloaded free of charge from:

https://scholarship.law.georgetown.edu/facpub/924

31 Int'l J. Legal Info. 290-311 (2003)

This open-access article is brought to you by the Georgetown Law Library. Posted with permission of the author. Follow this and additional works at: https://scholarship.law.georgetown.edu/facpub

Part of the Constitutional Law Commons, Human Rights Law Commons, Immigration Law Commons, and the National Security Law Commons 


\title{
Their Liberties, Our Security \\ Democracy and Double Standards
}

\author{
DAVID COLE*
}

To those who pit Americans against immigrants and citizens against non-citizens, to those who scare peace-loving people with phantoms of lost liberty, my message is this: Your tactics only aid terrorists, for they erode our national unity and diminish our resolve. They give ammunition to America's enemies, and pause to America's friends.

-Attorney General John Ashcroft, 6 December 2001

\section{INTRODUCTION}

On January 24, 2002, the United States military transported John Walker Lindh, a young American raised in Marin County, California, and captured with the Taliban on the battlefields of Afghanistan, to Alexandria, Virginia, where he was to be indicted in a civilian criminal court for conspiring to kill Americans. White House spokesman Ari Fleischer announced that "the great strength of America is he will now have his day in court." Represented by some of the best criminal defense attorneys in the country, Lindh raised substantial constitutional challenges to his prosecution, and the government ultimately dropped its most serious charges against him in exchange for a plea agreement.

" Professor of Law, Georgetown University Law Center. This article was originally published in the December 2002/January 2003 issue of Boston Review and is adapted from "Enemy Aliens," 54 Stanford Law Review 953 (2002) which is available at www. law.stanford.edu/lawreview/content/vol54/Cole.pdf. Readers interested in citations to authority should refer to that article. CDavid Cole 2003. 
At the same time, the military was holding 158 foreign-born Taliban and al Qaeda prisoners at a military base at Guantanamo Bay, Cuba, in eightfoot-by-eight-foot chain-link cages. A widely circulated press photo depicted the prisoners bound and shackled, with bags covering their heads and eyes, kneeling on the ground before U.S. soldiers. They were (and still are) held incommunicado, without charges, without access to lawyers, and without any judicial review. President George W. Bush announced that he categorically determined that the Guantanamo detainees were not entitled to the protections accorded prisoners of war under the Geneva Conventions, and Secretary of Defense Donald Rumsfeld dismissed concerns about their treatment with the assertion that they were "being treated vastly better than they treated anybody else over the last several years." Two months earlier, the president had issued a military order providing that al Qaeda members and other noncitizens could be tried by military tribunals, in which the military would act as prosecutor, judge, jury, and executioner, without any appeal to a civilian court.

The difference between the treatment afforded John Walker Lindh and his fellow Taliban and al Qaeda prisoners held at Guantanamo appeared to rest on the fact that Lindh was, as the press nicknamed him, "the American Taliban." When Attorney General John Ashcroft announced the charges against Lindh, a reporter asked why Lindh was being tried in an ordinary criminal court rather than before a military tribunal. Ashcroft explained that because Lindh was a United States citizen, he was not subject to the military tribunals created by President Bush's order. As a purely legal matter, the president could have made U.S. citizens subject to military commissions; citizens have been tried in military tribunals before, and the Supreme Court expressly upheld such treatment as recently as World War II. But the president chose to limit his order to noncitizens. Several months later, however, military justice was extended to U.S. citizens, as the government asserted the right to hold two citizens-Yaser Hamdi, captured in Afghanistan, and José Padilla, arrested at O'Hare Airport in May on suspicion that he might be planning to set off a radioactive "dirty bomb"-as "enemy combatants," without charges, without counsel, without trial, and without judicial review.

Both the president's initial choice to limit military justice to foreign nationals and his subsequent extension of that authority to U.S. citizens are emblematic of how we have responded to the terrorist attacks of September 11, 2001. While there has been much talk about the need to sacrifice liberty for a greater sense of security, in practice we have at least initially selectively sacrificed noncitizens' liberties while retaining basic protections for citizens. 
All too often, we have sought to avoid the difficult trade-offs between liberty and security by striking an illegitimate balance, sacrificing the liberties of noncitizens in furtherance of the citizenry's purported security. Because noncitizens have no vote, and thus no direct voice in the democratic process, they are an especially vulnerable minority. And in the heat of the nationalistic and nativist fervor engendered by war, noncitizens' interests are even less likely to weigh in the balance.

Some maintain that a "double standard" for citizens and noncitizens is perfectly justified. The attacks of September 11 were perpetrated by nineteen Arab noncitizens, and we have reason to believe that other Arab noncitizens are associated with the attackers and will seek to attack again. Citizens, it is said, are presumptively loyal; noncitizens are not. Thus, it is not irrational to focus on Arab noncitizens. Moreover, on a normative level, if citizens and noncitizens were treated identically, citizenship itself might be rendered meaningless. The very essence of war involves the drawing of lines in the sand between citizens of our nation and those against whom we are fighting. Surely in that setting it makes sense to treat noncitizens differently from citizens.

I will argue that such reasoning should be resisted on three grounds. First, it is normatively and constitutionally wrong: the basic rights at stake-political freedom, due process, and equal protection of the laws-are not limited to citizens, but apply to all "persons" subject to our laws. Second, it undermines our security interests: employing a double standard with respect to the basic rights accorded citizens and noncitizens is likely to be counterproductive at home and abroad because it compromises our legitimacy in both spheres. And third, it will pave the way for future inroads on citizens' liberties: as the government's treatment of Padilla and Hamdi has already illustrated, the tactic of trading immigrants' rights for citizens' security is misleading, for what we let our government do to immigrants creates precedents for how it treats citizens.

In short, when we balance liberty and security, we should do so in ways that respect the equal dignity and basic human rights of all persons and not succumb to the temptation of purchasing security at the expense of noncitizens' basic rights. The true test of justice in a democratic society is not how it treats those with a political voice, but how it treats those who have no voice in the democratic process. 


\section{SACRIFICING THEIR LIBERTY FOR OUR SECURITY: THE POST-9/11 RESPONSE}

"[S]omebody who comes into the United States of America illegally, who conducts a terrorist operation killing thousands of innocent Americans-men, women, and children-is not a lawful combatant. ... They don't deserve the same guarantees and safeguards that would be used for an American citizen going through the normal judicial process." With these words Vice President Dick Cheney defended the president's military order of November 13,2001, which authorized trial by military commission of any noncitizen whom the president accuses of engaging in international terrorism or belonging to al Qaeda. The vice president's view captures much of the administration's response to the attacks of September 11. Each of its initiatives raises serious constitutional concerns, and each imposes burdens on noncitizens' basic rights-burdens that citizens do not bear.

\section{Secret Preventive Detention}

Perhaps the most troubling feature of the government's response to the September 11 attacks has been its campaign of mass preventive detention. The actual number detained is a mystery because in early November 2001, when the number was 1,147 , the government responded to growing criticism of the number of persons it was detaining by halting its practice of issuing a running tally. Even if one assumes that arrests dropped substantially after the first seven weeks of the investigation, it is likely that somewhere between 1500 and 2000 persons have been detained in the more than twelve months that the investigation has continued. Yet not a single one of the post-9/11 detainees has been charged with involvement in the crimes under investigation. As of September 2002, only Zaccarias Moussaoui had been so charged, and he was arrested before the roundup began. Attorney General John Aschcroft has described the detainees as "suspected terrorists," yet by the one-year anniversary of the investigation, only four detained individuals had been charged with any terrorist-related crimes. Most of the detainees have been released or deported, after being affirmatively cleared of any involvement in terrorism by the FBI.

The detentions have been carried out under an unprecedented veil of secrecy. The government has refused to release any details regarding the 
identity of the detainees. And the vast majority of the detainees, those held on immigration charges, have been tried in proceedings closed to the public, the press, legal observers, and even family members. On orders from John Ashcroft, Chief Immigration Judge Michael Creppy has instructed immigration judges not to list the cases on the public docket and, if asked, to refuse to confirm or deny that they even exist. All hearings must be closed, no matter how routine and whether or not any sensitive issues are discussed. If another country were to lock up and try hundreds of people in secret, we would not hesitate to call the detainees "disappeared." Six of the eight federal judges who reviewed the government's practice of closing the immigration proceedings have ruled the practice unconstitutional, and another federal judge has ruled that the government violated the Freedom of Information Act in refusing to disclose the detainees' names. Yet the secrecy continues as the government appeals.

Many of those detained on immigration charges were initially held for weeks, and in some cases months, without any charges at all. More than 317 detainees were held for more than 48 hours before being charged, 36 detainees were held for more than four weeks without charges, and nine were held for more than fifty days without charges. Once charges are filed, they are generally "pretextual." The real reason for their incarceration is not that they worked without authorization or took too few academic credits, for example, both common violations of visas. Rather, the government has used these excuses to detain them because it thinks they might have valuable information, because it suspects them but lacks sufficient evidence to make a charge, or simply because the FBI is not yet convinced that they are innocent.

Consider, for example, Ali Maqtari. A Yemeni citizen, Maqtari was picked up on September 15 when he accompanied his U.S.-citizen wife to Fort Campbell, Kentucky, where she was reporting for Army basic training. Agents interrogated him for more than twelve hours and accused him of being involved with terrorists. Maqtari took and passed a lie detector test, but he was detained on the highly technical charge that he had been in the country illegally for ten days while changing his status from tourist to permanent resident. The government never offered any evidence linking him to terrorism or crime of any kind. It merely submitted a boilerplate affidavit from an FBI agent arguing that Maqtari should be detained because the investigation of terrorism is a "mosaic," and therefore, seemingly innocent facts might at some future time turn out to indicate culpability. Two months later, Maqtari was released without charges. 
Ibrahim Turkmen, a citizen of Turkey, was arrested and detained on October 13, 2001. About two weeks later an immigration judge granted Turkmen voluntary departure, which meant he was legally free to leave the country. Two days later, a friend purchased a plane ticket for him and brought it to the INS office. Yet the INS kept Turkmen in custody for nearly four more months, not because it had probable cause that he had committed any crimes, but simply because the FBI had not yet convinced itself that he was innocent.

The Constitution does not permit detention for investigative purposes. And immigration authorities have no freestanding authority to detain; they may do so only when necessary to effectuate a noncitizen's removal from the country. When a foreign citizen agrees to leave, there is no legitimate immigration purpose to keep him detained. Yet many noncitizens have remained in custody for months while the FBI investigates them and are allowed to leave only after the FBI clears them.

These and other cases suggest that Justice Department policy has been to lock up first, ask questions later, and presume that an alien is dangerous until the FBI has a chance to assure itself that the individual is not. The government has justified its actions with a liberal combination of the "mosaic" argument noted above and the "sleeper" theory. Under the latter, the fact that a suspicious person has done nothing illegal only underscores his dangerousness; al Qaeda is said to have "sleeper" cells around the world, groups of individuals living quiet and law-abiding lives but ready and willing to commit terrorist attacks once they get the call.

Most immigration judges apparently accepted that the absence of evidence of illegal conduct is not a reason to release a suspicious person. But when some judges declined to go along with the detentions and ordered that aliens be released on bond pending resolution of their deportation proceedings, Attorney General Ashcroft changed the rules. Under a new regulation issued October 29, 2001, even if an immigration judge rules after a custody hearing that the government has shown no basis for detention, an INS district director-in effect, the prosecutor-can keep the alien locked up simply by filing an appeal of the release order. A federal judge has also declared this rule unconstitutional.

If the New York police chief had investigated a serious violent crime by arresting hundreds of residents virtually all of one ethnicity, held and tried most of them in secret on pretextual charges, and failed after a year to charge 
even one of them with the crime under investigation, he would be out of a job. Yet complaints about the $9 / 11$ detainees have been muted. I believe the fact that virtually all of them are foreign citizens has allowed the citizenry a sense of comfort; these tactics will not apply to them. Citizens, after all, are entitled to a public trial. They may be subjected to "preventive detention" in connection with pending criminal charges, but only if brought before an independent judge within 48 hours of arrest for a hearing to determine whether there is probable cause that they have committed a crime, and only if they are also shown in a fair adversarial proceeding to be a flight risk or danger to the community. They are entitled to a "speedy trial," which means that unless they agree to an extension, preventive detention will be limited to a matter of weeks. In other words, we have imposed on foreign citizens widespread human rights deprivations that we would not tolerate if imposed on ourselves.

\section{The USA Patriot Act}

The targeting of noncitizens is further reflected in the USA Patriot Act, an omnibus antiterrorism bill enacted just six weeks after September 11. The act makes many changes to criminal, immigration, banking, and intelligence law, but it reserves its most extreme measures for noncitizens. For example, it makes noncitizens deportable for wholly innocent associational activity. Before September 11, aliens were deportable for engaging in or supporting terrorist activity, but not for mere association. Aliens could be deported for providing material support to an organization only if they knew or should reasonably have known that their activity would support the organization "in conducting a terrorist activity." The Patriot Act eliminates that requirement. It makes aliens deportable for wholly innocent associational support of a "terrorist organization," whether or not there is any connection between the alien's conduct and any act of violence, much less terrorism.

Under this law, for example, a pacifist immigrant who sent a book by Gandhi to the leader of a designated terrorist group to encourage him to forego violence would be deportable as a terrorist, and would have no defense that his intentions were honorable.

The Supreme Court has repeatedly held that individuals cannot be penalized for their political associations absent proof that the individual specifically intended to further a group's illegal ends, and that donations to a political group are a form of protected association. Some argue, however, that 
the threat from terrorist organizations abroad and the fungibility of money require adjustments to the constitutional prohibition on guilt by association. But that prohibition was forged in the crucible of a battle against a foe that seemed even more formidable at the time-the Communist Party. Congress deemed the Communist Party a foreign-dominated organization, backed by the world's competing superpower, which used sabotage and terrorism for the purpose of overthrowing the United States by force and violence; the Supreme Court accepted that finding. If association with such an organization deserves constitutional protection, as the Supreme Court repeatedly has ruled, surely association with much less powerful groups that have merely used or threatened to use a weapon at some point deserves similar protection.

The fungibility argument also proves too much, for it would authorize guilt by association whenever any organization engages in some illegal activity. Donations to the Democratic Party, it could be argued, "free up" resources that are used to violate campaign finance laws, yet surely we could not criminalize all support to the Democratic Party simply because it sometimes violates campaign finance laws. And the fungibility argument assumes that every marginal dollar provided to a designated group will be spent on violence, but in many cases that assumption is not warranted. No one would seriously contend, for example, that every dollar given to the African National Congress in the 1980s for its lawful anti-apartheid work in South Africa freed up a dollar that the ANC devoted to terrorist attacks.

The Patriot Act also resurrects ideological exclusion, the practice of denying entry to aliens purely on the basis of speech. It bars admission to aliens who "endorse or espouse terrorist activity," who "persuade others to support terrorist activity or a terrorist organization," or who are representatives of groups that express such views. Because of the breadth of the definitions of "terrorist activity" (virtually any act or threat of violence) and "terrorist organizations" (any group of two or more persons that engages in or threatens violence), this authority would empower the government to deny entry to any alien who advocated support for the ANC in the 1980s, for the Contras during the war against the Sandinistas, or for opposition forces in Afghanistan or even the government of Israel today.

Excluding people for their ideas is contrary to the spirit of political freedom for which the United States stands. It was for that reason that Congress removed all such grounds from the immigration laws in 1990, after years of embarrassing visa denials for political reasons. Yet we have now 
returned to the much-criticized ways of the McCarran-Walter Act, targeting aliens not for their acts but for their words-words that would be fully protected if uttered by United States citizens.

The Patriot Act also radically expands the government's authority to detain immigrants. It gives the attorney general unprecedented power to detain aliens indefinitely without a hearing and without showing that they pose a threat to national security or a flight risk. He need only certify that he has "reasonable grounds to believe" that the alien is "described in" various anti-terrorism provisions of the INA, provisions so broad that they would encompass a permanent resident alien who brandished a kitchen knife in a domestic dispute with her abusive husband or an alien who donated a box of crayons to a charitable day-care center associated with a "terrorist organization."

The Patriot Act also appears to permit detention of aliens indefinitely, even where they have prevailed in their removal proceedings. It provides that detention shall be maintained "irrespective of . . . any relief from removal granted the alien, until the attorney general determines that the alien is no longer an alien who may be certified." Holding such a person in custody is akin to holding a convicted prisoner after he has been pardoned.

\section{Ethnic Profiling}

One of the most dramatic responses to the attack of September 11 was a swift reversal in public attitudes about racial and ethnic profiling as a law enforcement tool. Before September 11, polls found that about 80 percent of the American public considered racial profiling wrong. State legislatures, local police departments, and President Clinton had condemned the practice and ordered data collection on the racial patterns of stops and searches. The U.S. Customs Service, sued for racial profiling, had instituted measures to counter racial and ethnic profiling at the borders. A federal law prohibiting racial profiling seemed likely. Even Ashcroft had criticized the practice and pledged to end it.

After September 11, however, polls reported that nearly 60 percent of the American public favored ethnic profiling directed at Arabs and Muslims. The fact that the perpetrators of the September 11 attack were all male Arab and Muslim immigrants and that the attack was orchestrated by al Qaeda has 
led many to believe that it is only common sense to pay closer attention to Arab-looking men boarding airplanes and elsewhere. The high stakes make the case for profiling stronger here than in routine drug interdiction stops on highways. Stuart Taylor, a columnist for Newsweek, the National Journal, and Legal Times, and a prior critic of racial profiling, wrote shortly after the attacks in favor of ethnic profiling of Arab men on airplanes. Press accounts made clear that, whether as a matter of official policy or not, law enforcement officials and airline employees were paying much closer attention to those who appear to be Arabs and Muslims.

While the Bush Administration has spoken out against ethnic and religious stereotyping and hate crimes, its actions have sent a different message. It called in eight thousand young men for interviews in connection with the September 11 investigation, based not on their actual ties or conduct but solely on the fact that they were young immigrant men from specified countries. The countries singled out were said to be those where support for al Qaeda was believed to exist: that is, Arab nations. In January 2002, the Justice Department decided to prioritize the deportation of aliens from Arab countries, again, simply because of their origin. And in August 2002, the INS announced that it would require aliens from selected Arab countries to register and be fingerprinted. These actions only encourage others to act as if Arab or Muslim identity is a permissible basis for suspicion.

\section{Military Tribunals}

The final example of the double standard at work is President Bush's November 2001 order creating military tribunals. As noted at the outset, the Supreme Court has interpreted the Constitution to permit any unlawful combatant to be tried in a military tribunal, irrespective of citizenship. Yet the president initially opted to limit the tribunals to noncitizens. It seems likely that this too was a politically opportunistic decision. The government's later attempt to extend similar detention authority to U.S. citizens Yaser Hamdi and Jose Padilla generated a groundswell of criticism. Thus far the courts have rejected the government's assertion of entirely unchecked detention authority and have required some measure of justification for any such detention of a citizen. If the tribunal order had applied more broadly to citizens, the citizenry would have had a much more immediate interest in questioning the president's assertion of power. The military tribunals provide an extraordinary form of justice, as they do away with independent judicial review and make the 
determination of guilt solely a matter of military judgment by officials ultimately answerable in the chain of command to the president as Commander-in-Chief, on whose behalf the prosecution is brought. Moreover, the tribunals permit the use of classified evidence, presented ex parte and in camera, to convict suspects and do not permit access to that evidence by anyone outside the military chain of command. Such measures may or may not be justified in wartime, but the important point for current purposes is that it was politics, not law, that led the administration to restrict the tribunals to noncitizens.

\section{Citizens' Rights}

By contrast, security proposals that would directly affect us all, such as national identity cards, airport screening measures, and the Justice Department's Operation TIPS program, have received far more careful scrutiny than initiatives directed at immigrants. The proposal to create a national identity card has been on the table since September 12, but has gone nowhere. And when Operation TIPS came to light, in which the Justice Department plans to recruit eleven million private citizens to spy on their neighbors, to be drawn primarily from the ranks of those who have some reason to gain access to people's homes-such as delivery personnel and meter readers-it was roundly criticized by voices on all sides of the political spectrum, from Phyllis Schlafly to the ACLU. And at House Majority Leader Dick Armey's insistence, the Republicans' Homeland Security Bill expressly prohibited adoption of either a national identity card or Operation TIPS.

In addition, while federal courts have ruled certain aspects of Ashcroft's detention campaign illegal, they have principally done so at the behest of citizens, not immigrants. Several courts have ruled that U.S. citizens and the press have a First Amendment right to attend deportation hearings. Only one court has ruled that the aliens themselves have a due process right to a public trial. And the federal court that ordered disclosure of the detainees' names did so to vindicate the rights of U.S. citizens' right to know, not aliens' rights not to be disappeared. The courts have refused even to hear the claims of the foreign nationals held as enemy combatants at Guantanamo, but have been more solicitous of claims on behalf of U.S. citizens. When citizens' rights are directly at stake, in other words, the legal and political processes have proven much more rights-sensitive. When only immigrants' rights appear to be at risk, the system hardly blinks. 


\section{RESISTING DOUBLE STANDARDS}

As a way of striking the difficult balance between liberty and security, sacrificing foreign citizens' liberties is undoubtedly tempting. It allows those of us who are citizens to trade someone else's liberties for our security. We can avoid the difficult trade-offs, and have our security and our liberty, too. But doing so is wrong as a constitutional and normative matter, unlikely to make us more secure, and virtually certain to come back to haunt us.

\section{Bill of Rights as Human Rights}

As a constitutional matter, basic rights such as due process, equal protection, and the freedoms of speech and association are not limited to citizens, but apply to all "persons" within the United States or subject to U.S. authority. The Constitution does restrict the right to vote to citizens, but that restriction only underscores by contrast that the Constitution's other rights apply to all "persons." These are human rights, not privileges of citizenship. At the time of the framing, they were seen as divinely decreed natural rights; in today's world, they are the core of what we understand as international human rights, owed to all persons by virtue of their personhood, irrespective of their identity or the political character of their government. The Supreme Court has stated that the First and Fifth Amendments acknowledge no distinction between citizens and foreigners residing in the United States, and as recently as 2001 the Court reaffirmed that "the Due Process Clause applies to all persons within the United States, including aliens, whether their presence here is lawful, unlawful, temporary, or permanent." Moreover, the very fact that noncitizens lack the vote only makes it all the more essential that they receive judicial protection, as they cannot rely on the political process to consider their interests.

In addition, as the late renowned Yale law professor Alexander Bickel argued, past experience with limiting rights on the basis of citizenship should give us pause. The Supreme Court's decision in Dred Scott v. Sanford sought to deny Dred Scott's rights by concluding that "persons who are descendants of Africans who were imported into this country, and sold as slaves," were not citizens and therefore could not invoke federal court jurisdiction. The Court reasoned that when the Constitution was adopted blacks were not protected by its provisions because they were "considered as a subordinate and inferior class 
of beings, who had been subjugated by the dominant race, and, whether emancipated or not, yet remained subject to their authority, and had no rights or privileges but such as those who held the power and the Government might choose to grant them."

With the express intent of overruling that reasoning, Congress provided in the Civil Rights Act of 1866 that "all persons born in the United States and not subject to any foreign power, excluding Indians not taxed, are hereby declared to be citizens of the United States." The same Congress enacted the Fourteenth Amendment, which provided that all persons born or naturalized in the United States are citizens and further guaranteed to all persons in the United States-whether citizens or not-due process of law and equal protection. As Bickel argued, Dred Scott teaches that "[a] relationship between government and the governed that turns on citizenship can always be dissolved or denied [because] [c]itizenship is a legal construct, an abstraction, a theory." It is far more difficult to deny that a human being is a "person."

\section{Undermining Security}

Double standards are also unlikely to make us more secure. Even granting that it is rational to assume that al Qaeda operatives are more likely to be Arab or Muslim, if we are going to identify and capture the few al Qaeda terrorists among the many millions of law-abiding Arabs and Muslims here and abroad, we need the full cooperation of those communities. The communities themselves are much better equipped to identify the terrorists residing among them than are a group of outside law enforcement officials largely unfamiliar with the language, culture, and community. But when we impose on Arabs and Muslims burdens that we would not tolerate for ourselves, we make the targeted communities far less likely to cooperate and simultaneously stoke anti-American sentiments. And when we single out citizens of Arab countries for treatment not accorded to other nationals, those countries are likely to be less eager to assist in the war on terrorism as well.

At the same time, when the government departs from individual culpability and adopts guilt by association or suspicion by ethnicity as guiding principles, it encourages sloppy policing and wasteful expenditure of resources on the innocent. The proxies of ethnicity and political or religious association are so inexact and overboard that the vast majority of those questioned or detained are certain to be wholly innocent. 
To cite one example, the federal government has now been attempting to deport a group of seven Palestinians and a Kenyan in Los Angeles for nearly sixteen years. (I have been defending the group for the same period of time). The group came to the FBI's attention in the early 1980s in connection with counter terrorism investigations relating to the 1984 Los Angeles Olympics. Most of the eight were college students at the time and were vocally supportive of Palestinian self-determination.

The FBI spent three years investigating them, including extensive video and electronic surveillance, renting a home next door to two of the individuals for six months, and frequent spells of round-the-clock surveillance. One of the things the students did was to organize annual dinners for the Palestinian community. The events were widely publicized and open to anyone. As many as a thousand people attended, including many families and children. The events featured Palestinian food, music, dancing, and speeches. In addition, at the close of the evening there was generally a charitable fundraising pitch. Suspecting that these events may be linked to an alleged terrorist group called the Popular Front for the Liberation of Palestine (PFLP), FBI agents attended one of the events and wrote the following report:

The Federal Agents observing the fund raiser did not speak or understand the Arabic language, however, from the posters of Palestinians with AK-47 assaults [sic] rifles and the general mood or tone of the speeches, the agents realized that the PFLP was not attempting to raise money for a humanitarian cause. The music and entire mood of the fund raiser from the entrance ceremony through the speeches sounded militaristic.

The fact that the FBI would not even bother to have someone attend the event who could speak Arabic is an illustration of what happens when one proceeds under a principle of guilt by association. If all one needs to prove is association, one need not do the difficult work of determining whether in fact the individuals are engaged in any criminal or terrorist activity. In the end, the FBI concluded that it had no evidence that any of the individuals had committed any criminal or terrorist activity, but nonetheless urged the INS to deport them for their political associations. 


\section{The Illusory Double Standard}

As it happens, you can't really have your cake and eat it, too. The argument that we are only targeting aliens' rights, and therefore citizens need not worry, is in an important sense illusory, for what we do to aliens today provides a precedent for what can and will be done to citizens tomorrow. When the president introduced the concept of military justice with his military tribunal order in November, for example, he reassured Americans that it would not apply to them but only to noncitizens. Yet now the administration has crossed that line and asserted the same authority with respect to the two U.S. citizens, Hamdi and Padilla, that it asserts with respect to the foreign citizens held at Guantanamo. The military claims that simply by attaching the label "enemy combatant," the president can authorize the indefinite, incommunicado incarceration of any U.S. citizen he chooses, without access to counsel and without judicial review. Military justice has come home to roost. This proposition is so extreme that even the U.S. Court of Appeals for the Fourth Circuit, by far the most conservative federal circuit in the country, has rejected it. Yet the Wall Street Journal reported in August that high-level administration officials have advocated even broader reliance on this power and have suggested creating a special camp to house more citizen "enemy combatants."

The line between alien and citizen has often been crossed before. In fact, two of the most shameful episodes of our nation's history also had their provenance in measures initially targeted at noncitizens. The McCarthy era of the 1940s and 1950s, in which thousands of Americans were tarred with guilt by association, was simply an extension to citizens of a similar campaign using similar techniques against alien radicals in the first Red Scare thirty years earlier. The earlier Red Scare, which culminated in the arrests of thousands of aliens for their political associations during the Palmer Raids, was coordinated by a young J. Edgar Hoover, then in the Alien Radical division of the Justice Department. Hoover applied what he had learned in the first Red Scare to U.S. citizens during the second Red Scare, which targeted thousands of them.

The same pattern underlies the internment of U.S. citizens of Japanese descent during World War II. Since 1798, the Enemy Aliens Act has authorized the president during wartime to arrest, detain, deport, or otherwise restrict the freedom of anyone over fourteen years old who is a citizen of the country with which we are at war, without regard to any actual evidence of 
disloyalty, sabotage, or danger. The justification for that law, which the Supreme Court has upheld as constitutional, is that during wartime one can presume that citizens of the enemy country are loyal to their own country, not ours, and that there is insufficient time to identify those who are actually disloyal.

In World War II we simply extended that argument to U.S. citizens through the prism of race. The Army argued that persons of Japanese descent, even if they were technically American citizens because they were born here, remained for all practical purposes "enemy aliens, " presumptively likely to be loyal to Japan. Lt. General John L. DeWitt, the driving force behind the internment orders, wrote in his report on the Japanese evacuation that "[t]he Japanese race is an enemy race and while many second and third generation Japanese, born on United States soil, possessed of United States citizenship, have become Americanized, the racial strains are undiluted." More colloquially, General DeWitt testified in 1943 before the House Naval Affairs Committee, that "[a] Jap's a Jap . . . It makes no difference whether he is an American citizen or not." And so we locked up 110,000 persons solely because of their Japanese ancestry, 70,000 of them U.S. citizens.

The pattern is also evident in more recent history, much of which I have experienced first-hand as a constitutional lawyer for the Center for Constitutional Rights. When the eight Los Angeles-based Palestinian activists referred to above were arrested in January 1987, FBI Director William Webster testified in Congress that a three-year FBI investigation had found no evidence of criminal or terrorist activity, but that the individuals "were arrested because they are alleged to be members of a world-wide Communist organization which, under the McCarran Act, makes them eligible for deportation," and that "if these individuals had been United States citizens, there would not have been a basis for their arrest." The INS district director explained that the INS sought their deportation "at the behest of the FBI, which concluded after investigating [the eight] that it had no basis for prosecuting [them] criminally."

Contemporaneous FBI memoranda prepared to urge the INS to deport the eight aliens confirm that they were targeted solely for lawful political associations and advocacy that would be fully protected if engaged in by U.S. citizens. The memoranda consist entirely of accounts of lawful political activity. The memos repeatedly criticize the aliens' political views as "anti-US, anti-Israel, anti-Jordan," and even "anti-REAGAN and anti-MABARAK [sic]." 
Over three hundred pages are devoted to tracking compulsively the distribution of PFLP newspapers, available in public libraries throughout the United States, as if they were illegal drugs. Agents intercepted boxes of magazines imported from abroad at the Los Angeles airport, weighed them to estimate how many magazines they contained, and then carefully tracked those who picked up and distributed the magazines.

The principal FBI report on the group admitted that the FBI's purpose was "to identify key PFLP people in Southern California so that law enforcement agencies capable of disrupting the PFLP's activities through legal action can do so," even though the FBI had found no evidence of illegal activities. The FBI specifically urged deportation of the alleged "leader" of the group, Khader Hamide, not because he engaged in any criminal acts, but because he was "intelligent, aggressive, dedicated, and shows great leadership ability."

Even though Congress in 1990 repealed the immigration law provisions that made aliens deportable for associating with groups advocating communism, the INS continued its deportation efforts, pursuing some of the eight on routine visa violation charges and charging the two who were permanent residents with having "engaged in terrorist activity" by providing material support to the PFLP. The aliens obtained an injunction against the deportation proceedings, successfully arguing that they had been singled out for deportation based on First Amendment-protected activities. In opposing the injunction, the government argued that aliens enjoyed only diminished First Amendment rights and that therefore the INS should be permitted to single out aliens for deportation based on their association with and support of a terrorist group without having to show that the conduct in any way furthered any terrorist activity.

The federal courts rejected this argument, holding that aliens in the United States are entitled to the same First Amendment rights as citizens. In 1996 , however, the INS persuaded Congress to repeal federal court jurisdiction to hear cases challenging selective enforcement of the immigration law, and the Supreme Court ruled that the aliens' challenge to their deportation should be dismissed, with a gratuitous aside suggesting that selectively targeting aliens for deportation for their associations is constitutionally acceptable. To this day, nearly sixteen years after the initial arrests, the government continues to seek the aliens' deportation, notwithstanding its initial admission that they have engaged in no illegal or terrorist activity. From the government's perspective, 
that admission is not material because any support to a "terrorist group," even to its wholly lawful activities, should be a legally sufficient basis for deportation.

In the Los Angeles deportation case the government consistently argued that aliens were entitled to reduced First Amendment protection. But as in the World War II and McCarthy era periods, its arguments were soon extended to citizens. In the 1996 Anti-Terrorism and Effective Death Penalty Act, Congress made it a crime, punishable by ten years in prison and a substantial fine, to provide any material support to a designated terrorist organization. Prior law had criminalized material support of terrorist activity, which required the government to show some connection between an individual's support and the terrorist activity. Just as the Patriot Act later did with respect to immigration law, the 1996 statute dispensed with the requirement that the government prove a nexus to terrorist activity for criminal prosecutions. Under this law, like the Patriot Act, a person who supports a designated organization is liable even if he can show that his support was designed to discourage the group from engaging in violence and actually had that effect. Here again, then, a theory initially used against aliens and defended on the ground that aliens deserve less constitutional protection than citizens proved to be a precursor for a similar law directed at citizens.

One practice that one might think citizens need not worry about is the use of secret evidence to determine the outcome of legal proceedings concerning their liberty or property. The Confrontation Clause guarantees that anyone tried in a criminal court has a right to confront the evidence used against him, and the elemental due process requirement that persons be afforded a meaningful opportunity to be heard would seem to require access to the dispositive evidence used to take one's liberty or property. Yet the government has for fifty years used secret evidence submitted in camera and ex parte in immigration proceedings and has argued that aliens are not constitutionally entitled to confront the evidence against them even when their physical liberty is at stake. Here, too, the government has maintained that aliens enjoy only diminished constitutional protections. But here, too, the government has sought to extend this practice to United States citizens.

Consider the case of Hany Kiareldeen, a Palestinian in his thirties who came to the United States on a student visa in 1990 and now lives in Newark, New Jersey. In March 1998, the INS arrested Kiareldeen, charged him with 
failing to maintain his student visa status, and detained him without bond, claiming that he was a threat to national security.

Kiareldeen never saw the evidence that allegedly supported his detention as a security threat because the INS submitted it to an immigration judge in camera and ex parte. The INS did give Kiareldeen an unclassified summary of the evidence, but the summary initially disclosed only that he was allegedly associated with terrorists and posed a threat to the attorney general, charges so general that Kiareldeen could not possibly rebut them.

Subsequently, the INS expanded its disclosure and ultimately revealed three allegations: 1) that Kiareldeen was associated with an unidentified "terrorist organization" and with other members and suspected members of terrorist organizations, also unidentified; 2) that about a week before the first World Trade Center bombing, Kiareldeen hosted a meeting at his residence in Nutley, New Jersey, where some individuals discussed plans to bomb the World Trade Center; and 3) that "Kiareldeen expressed a desire to murder Attorney General Janet Reno." The summary provided no further details. It did not, for example, identify the sources for any of these allegations, nor did it explain the context or time frame for the alleged relationships and statement.

Kiareldeen was nonetheless able to rebut the government's case in open court. He proved, for example, that he did not even live in the apartment where he supposedly hosted a meeting with World Trade Center bombers until a year and a half after the alleged meeting took place. He showed that his phone records from the time revealed no phone calls to other conspirators in the World Trade Center case, while the conspirators' phone records showed extensive calls among themselves. And he testified that one of the sources of secret evidence against him, his ex-wife, had made numerous false allegations against him in the course of a custody battle over their child. Kiareldeen sought to examine his ex-wife in open court, but the INS vigorously opposed his attempts to do so, and she refused to testify about her discussions with the FBI.

In the end, all seven immigration judges who examined the complete record in Kiareldeen's case, including the government's secret evidence presentation and Kiareldeen's open court rebuttal, rejected the government's contention that he posed a threat to national security, and he was eventually released-but not before he spent nineteen months in jail on the basis of that secret evidence. 
Kiareldeen is not alone. Since 1987 I have represented thirteen aliens against whom the government has sought to use secret evidence either to detain or to deport them. In each case the government claimed that the evidence showed the aliens to be threats to national security. Yet in each case the aliens were eventually released by court order, either because federal courts concluded that reliance on classified evidence was unconstitutional, or because once the government disclosed some of the classified evidence, the alien was able to rebut the charges in immigration court. In each case in which the charges were disclosed, they consisted of little more than guilt by association. (One of the thirteen, Mazen Al-Najjar, a Palestinian adjunct professor at University of South Florida, was subsequently rearrested and deported after September 11. The government argued that it could detain Al-Najjar without any evidence that he posed a danger or flight risk. Al-Najjar challenged that position in court, but was deported before the legal challenge to his custody concluded).

In the wake of September 11 the use of secret evidence has now been extended to domestic law affecting citizens. The Treasury Department, relying on the Patriot Act, has seized all property and blocked all bank accounts of three U.S.-based charities: Holy Land Foundation, Global Relief Foundation, Inc., and Benevolence International Foundation, Inc. In each case it did so without notice or an opportunity for a hearing. When the charities, all American corporations with U.S.-citizen board members, sued to challenge the legality of the seizures, the government argued that the organizations had no right to present evidence in their own defense. In addition, the government invoked a provision of the Patriot Act that authorizes it to present classified evidence in camera and ex parte to defend the seizures.

Nor is this the first time that the use of secret evidence has been extended from immigrants to citizens. In the Cold War the government extended the practice to citizens as well, as both the House Un-American Activities Committee and federal employment loyalty review boards required suspects to answer charges made in secret by anonymous informants and denied those accused any opportunity to confront their accusers.

History reveals that the distinction between citizen and alien has often been resorted to as a justification for liberty-infringing measures in times of crisis. In the short term, the fact that measures are limited to noncitizens appears to make them easier for the majority to accept-citizens are not asked to sacrifice their own liberty. But the same history suggests that citizens should 
be wary about relying on this distinction because it has often been breached before. What we are willing to do to noncitizens ultimately affects what we are willing to do to citizens. In the long run, all of our rights are at stake in the war against terrorism.

\section{CONCLUSION}

Security is indisputably at a premium in the wake of the attacks of September 11. There may well be justification for sacrificing some of our liberties if the sacrifice will make us more secure. But many of the measures we have undertaken after September 11 follow a disturbing historical pattern, in which we, the citizenry, sacrifice not our freedoms but the freedoms of noncitizens, a minority group with no vote, in the interest of preserving citizens' security. The post-September 11 response constitutes a reprise of some of the worst mistakes of our past. Once again, we are treating people as suspicious not for their conduct, but based on their racial, ethnic, or political identity. Once again, we are using the immigration power as a pretext for criminal law enforcement without the protections associated with the criminal process. Once again, we have undertaken a mass detention campaign directed at immigrants without probable cause that any of them are tied to the specific threats that we face. And once again, we have authorized the government to bypass procedures designed to distinguish the guilty from the innocent, holding secret hearings and authorizing executive detentions that challenge the most basic notions of fairness.

As politically tempting as the trade-off of immigrants' liberties for our security may appear, we should resist it for reasons of principle, pragmatism, and self-interest. As a matter of principle, the rights that we have selectively denied to immigrants should not be reserved for citizens. The rights of political freedom, due process, and equal protection belong to every person subject to U.S. legal obligations, irrespective of citizenship. As a pragmatic matter, reliance on double standards reduces the legitimacy of our struggle, and that legitimacy may be our most valuable asset, both at home and abroad. To paraphrase John Ashcroft himself: "To those who pit Americans against immigrants and citizens against non-citizens . . my message is this: Your tactics only aid terrorism." And as a matter of self-interest, what we do to aliens today may well pave the way for what will be done to citizens tomorrow. In the end, however, it is principle that should drive us: the justice of our 
response should be judged by how we treat those who have no voice in the political process. Thus far, we have performed predictably, but not well. 